Pesq. Vet. Bras. 35(1):67-74, janeiro 2015

DOI: $10.1590 / \mathrm{S} 0100-736 \mathrm{X} 2015000100014$

\title{
Plasmodium spp. and Haemoproteus spp. infection in birds of the Brazilian Atlantic Forest detected by microscopy and polymerase chain reaction ${ }^{1}$
}

\author{
Raquel Tostes ${ }^{2 *}$, Usha Vashist ${ }^{3}$, Kézia K.G. Scopel ${ }^{4}$, Carlos L. Massard ${ }^{2}$, \\ Erik Daemon $^{5}$ and Marta D'Agosto ${ }^{5}$
}

\begin{abstract}
Tostes R., Vashist U., Scopel K.K.G., Massard C.L., Daemon E. \& D’Agosto M. 2015. Plasmodium spp. and Haemoproteus spp. infection in birds of the Brazilian Atlantic Forest detected by microscopy and polymerase chain reaction. Pesquisa Veterinária Brasileira 35(1):67-74. Curso de Pós-Graduação em Ciências Veterinárias, Instituto de Veterinária, Universidade Federal Rural do Rio de Janeiro, BR-465 Km 7, Seropédica, RJ 23890-000, Brazil. E-mail: raquelctostes@yahoo.com.br

In recent years haemosporidian infection by protozoa of the genus Plasmodium and Haemoproteus, has been considered one of the most important factors related to the extinction and/or population decline of several species of birds worldwide. In Brazil, despite the large avian biodiversity, few studies have been designed to detect this infection, especially among wild birds in captivity. Thus, the objective of this study was to analyze the prevalence of Plasmodium spp. and Haemoproteus spp. infection in wild birds in captivity in the Atlantic Forest of southeastern Brazil using microscopy and the polymerase chain reaction. Blood samples of 119 different species of birds kept in captivity at IBAMA during the period of July 2011 to July 2012 were collected. The parasite density was determined based only on readings of blood smears by light microscopy. The mean prevalence of Plasmodium spp. and Haemoproteus spp. infection obtained through the microscopic examination of blood smears and PCR were similar (83.19\% and $81.3 \%$, respectively), with Caracara plancus and Saltator similis being the most parasitized. The mean parasitemia determined by the microscopic counting of evolutionary forms of Plasmodium spp. and Haemoproteus spp. was $1.51 \%$. The results obtained from this study reinforce the importance of the handling of captive birds, especially when they will be reintroduced into the wild.
\end{abstract}

INDEX TERMS: Avian malaria, Haemosporida, Plasmodium spp., Haemoproteus spp., wild birds, PCR, light microscopy.

\footnotetext{
${ }^{1}$ Received on August 13, 2014.

Accepted for publication on December 15, 2014.

${ }^{2}$ Curso de Pós-Graduação em Ciências Veterinárias, Instituto de Veterinária, Universidade Federal Rural do Rio de Janeiro (UFRRJ), BR-465 Km 7, Seropédica, RJ 23890-000, Brazil. *Corresponding author: raquelctostes@ yahoo.com.br

${ }^{3}$ Universidade Federal de Alfenas, Rua Gabriel Monteiro da Silva 700, Alfenas, MG 37130-000, Brazil.

${ }^{4}$ Departamento de Parasitologia, Microbiologia e Imunologia, Instituto de Ciências Biológicas, Universidade Federal de Juiz de Fora, Rua José Lourenço Kelmer s/n, Campus Universitário, Juiz de Fora, MG 36036-900, Brazil.

${ }^{5}$ Curso de Pós-Graduação em Ciências Biológicas, Comportamento e Biologia Animal, Instituto de Ciências Biológicas, Universidade Federal de Juiz de Fora, Rua José Lourenço Kelmer s/n, Campus Universitário, Juiz de Fora, MG 36036-900.
}

RESUMO.- [Infecção por Plasmodium spp. e Haemoproteus spp. em aves da Mata Atlântica brasileira detectada por microscopia e reação em cadeia da polimerase.] Nos últimos anos infecção por protozoários hemosporídeos dos gêneros Plasmodium e Haemoproteus, tem sido considerada um dos fatores mais importantes relacionados com a extinção e / ou declínio da população de várias espécies de aves em todo o mundo. No Brasil, apesar da grande biodiversidade aviária, poucos estudos foram desenvolvidos para detectar a infecção, especialmente entre as aves silvestres mantidas em cativeiro. Assim, o objetivo deste estudo foi analisar a prevalência de infecção por Plasmodium spp. e Haemoproteus spp. em aves silvestres em cativeiro na Mata Atlântica do sudeste do Brasil, utili- 
zando microscopia convencional e reação em cadeia da polimerase. Amostras de sangue de 119 aves mantidas em cativeiro no Ibama durante o período de julho de 2011 a julho de 2012, foram coletadas. A densidade parasitária foi determinada com base apenas em leituras de esfregaços de sangue por microscopia fotônica. A prevalência média de infecção por Plasmodium spp. e Haemoproteus spp. obtida por exame microscópico de esfregaços sanguíneos e PCR foi semelhante $(83,19 \%$ e $81,3 \%$, respectivamente), com Caracara plancus e Saltator similis sendo as espécies mais parasitadas. A parasitemia média determinada pela contagem microscópica de formas evolutivas de Plasmodium spp. e Haemoproteus spp. foi de 1,51\%. Os resultados obtidos neste estudo reforçam a importância do manejo de aves em cativeiro, especialmente quando serão reintroduzidas na natureza.

TERMOS DE INDEXAÇÃ̃: Malária aviária, Haemosporida, Plasmodium spp., Haemoproteus spp., aves silvestres, PCR, microscopia.

\section{INTRODUCTION}

Haemosporidian protozoa of the genus Plasmodium Marchiafava et Celli, 1885 and Haemoproteus Kruse, 1890 have a broad geographic distribution and a diversity of vectors, and have been described throughout the world as parasitizing several hosts, including birds, mammals and reptiles (Garnham 1966, Valkiūnas 2005). In birds, these parasites, has been described as a potential cause of extinction and population decline (Van Riper III et al. 1986, Atkinson et al. 1995, 2000, Massey et al. 1996), reducing the fitness of their hosts (Lefèvre et al. 2008) and may sometimes lead to death (Donovan et al. 2008, Cannell et al. 2013). Severe infections by haemosporidian can lead to death and involves different physiopathological phenomena such as anemia, thrombocytopenia and inflammation (Macchi et al. 2013, Cannell et al. 2013).

In Brazil, some studies have investigated the occurrence of parasitism by Plasmodium spp. and Haemoproteus spp. in wild birds in areas with different ecological characteristics and very different conservation (Bennett and Lopes 1980, Woodworth-Lynas et al. 1989, Ribeiro et al. 2005, Fecchio et al. 2007, 2011, 2013, Belo et al. 2009, 2011, Bueno et al. 2010, Lima et al. 2010, Sebaio et al. 2010, Andery et al. 2013, Chagas et al. 2013, Lacorte et al. 2013, Silveira et al. 2013, Vanstreels et al. 2014). However, little is known about the diversity of hemoparasites of birds in the Atlantic Forest of Southeastern Brazil. Moreover, few studies have been conducted to investigate the prevalence of haemosporidian in captive birds. Clark et al. (2014) highlight the importance of studies with haemosporidian in South America, since it is the region with the greatest diversity of lineages described for these hemoparasites, mainly of the genus Plasmodium. And considering that Brazil is a country with a valuable avian biodiversity, which leads to a large number of annual arrests for domestic and international bird trafficking, it is extremely important to know the variety and intensity of parasitic infections that such animals can present, as many tend to be reintroduced into the wild.
In birds, the detection and identification of haemosporidian species may occur via the morphology and morphometry of erythrocyte stages, including the length, width, area, size and number of hemozoin granules (Garnham 1966, Valkiūnas 2005) and through the amplification and sequencing of DNA (Bensch et al. 2000, 2009, Ricklefs \& Fallon 2002, Hellgren et al. 2004, Waldenström et al. 2004, Martinsen et al. 2006, 2008, Palinauskas 2009, 2011, 2013a, Valkiūnas et al. 2010, 2013, 2014). Some studies have shown that both methods can have similar sensitivities for detection of these hemoparasites (Perkins \& Schall 2002, Križanauskiené et al. 2006, 2010, Hellgren et al. 2007, Palinauskas et al. 2007, Valkiūnas et al. 2008, 2009a, 2014, Braga et al. 2011).

This study aimed at analyzing the prevalence and parasite density of Plasmodium spp. and Haemoproteus spp. in wild birds in captivity in the Atlantic Forest of Southeastern Brazil using microscopic and molecular analyses.

\section{MATERIALS AND METHODS}

Blood collection and handling of the birds. The study was conducted in a Brazilian federal environmental agency, the National Institute for the Environment and Renewable Natural Resources (IBAMA), where birds are received the population or are seized from illegal captivity. The study was approved by the Animal Experimentation Ethics Committee of Juiz de Fora Federal University (protocol no 027/2011) and the System for Authorization and Information on Biodiversity (SISBIO). The birds sampled for this study were maintained with birds of the same species or different species. No information on the time spent in captivity, retrospective of the study, was available. Furthermore, no parasitological examination was conducted to investigate the general health of the birds at the exact moment they were seized. No clinical signs and physical appearance of the birds were examined.

Preparation of smears and morphological analysis. For the observation of blood hemoparasites, samples were collected from 119 birds between July 2011 and July 2012. The volume of blood collected was $50 \mu \mathrm{L}$ (mean), not exceeding $1 \%$ of the live weight of the animal, as recommended by SISBIO, Campbell (1995) and Clark et al. (2009). The blood was collected by puncture of the brachial vein and was used for the preparation of blood smears and/or for PCR testing.

To calculate the prevalence of infection, parasitemia counting, identification and morphological characterization of hemoparasites from four blood smears were performed at the site collection according to Valkiūnas (2005). These smears were air dried and were fixed in methanol P.A. for $3 \mathrm{~min}$ and stained with Giemsa stain, diluted in distilled water (1:9), for $45 \mathrm{~min}$. The smears were examined under a light microscope (Olympus BX-51) at 1000x. A smear was examined for each bird, with one hundred microscopic fields of examination performed. However, when no parasite was observed, another smear was examined to confirm the result. The number of evolutive forms of Plasmodium spp. or Haemoproteus spp. found in each smear was recorded. The prevalence was calculated according to Bush et al. (1997), and parasitemia was calculated for each bird as proposed by Godfrey et al. (1987).

DNA extraction and molecular analysis. Of the 119 birds captured, venous blood was collected for molecular analysis from 80. After collection, the blood was immediately packed into $1.5 \mathrm{~mL}$ microtubes without anticoagulant, as suggested by SISBIO and Khosravinia \& Ramesha (2007). Blood samples were placed 
on ice, followed by storage at $-20^{\circ} \mathrm{C}$ until DNA extraction. The Wi$\operatorname{zard}^{\circledR}$ Genomic DNA Purification Kit (Promega MA, USA) was used for DNA extraction as described by the manufacturer.

For the amplification of the cytochrome b gene (cyt $b$ ) by polymerase chain reaction (PCR), the following primers were used: $P F$ (5'-GGA TTT GTG GTG GAT ATC TTG-3') and 4292Rw (5'-TGG AAC AAT ATG TAR AGG AGT-3'), as proposed by Merino et al. (2008). These primers will amplify the genus Plasmodium and Haemoproteus, which was shown by Martínez et al. (2009). This primer set amplifies a $320 \mathrm{bp}$ fragment. The PCR consisted of a final volume of $25 \mu \mathrm{L}$ containing, $12.5 \mu \mathrm{L}$ of Go Taq ${ }^{\circledR}$ Green Master Mix (Promega, MA, USA), $1.64 \mu \mathrm{L}$ of each primer at $10 \mu \mathrm{M}$ concentration and $2 \mu \mathrm{L}$ of genomic DNA. As a positive control, a DNA sample from Plasmodium juxtanucleare Versiani et Gomes, 1941 obtained in a study of experimental infection in Gallus gallus Linnaeus, 1758 was used. For a negative control, was used the Master Mix Kit but substituted ultrapure water for the DNA. The negative control also allowed the monitoring of contamination. The reactions were carried out in a thermocycler TECHNE TC 412 (Analítica ${ }^{\circledR}$ ) with the following conditions according by Merino et al. (2008): denaturation at $94^{\circ} \mathrm{C}$ for 10 minutes, 40 cycles of amplification at $95^{\circ} \mathrm{C}$ for 40 seconds, $58^{\circ} \mathrm{C}$ for 1 minute and $72^{\circ} \mathrm{C}$ for 1 minute and a final extension $72^{\circ} \mathrm{C}$ for 10 minutes. At least $20 \%$ of the samples were randomly selected, and the amplification reaction was repeated to ensure the reproducibility of the technique.

All PCR products were subjected to electrophoresis through a $1.5 \%$ agarose gel (Invitrogen ${ }^{\circledR}$ ) with $2.5 \mu \mathrm{L}$ of Loading Dye Blue Green I (LGC Biotechnology ${ }^{\circledR}$ ) for visualization of the amplified fragment. To determine the size of the fragment $10 \mu \mathrm{L}$ of $100 \mathrm{bp}$
DNA ladder (Promega ${ }^{\circledR}$ ) was used. The gels were visualized and photographed under ultraviolet light using a GE Healthcare ${ }^{\circledR}$ UV transilluminator.

\section{RESULTS}

Fourteen families and 36 species of birds were identified among the 119 birds captured (Table 1). The species with the highest number of sampled individuals were Saltator similis d'Orbigny \& Lafresnaye, $1837(\mathrm{n}=37 ; 31 \%)$ and Psittacara leucophthalmus (Statius Muller, 1776) ( $\mathrm{n}=20 ; 17 \%)$ (Table 1). By the microscopic examination of blood smears, 99 of the 119 birds were found to be infected with evolutive forms of Plasmodium spp. or Haemoproteus spp., with an overall prevalence of $83.19 \%$ (Fig.1). The mean parasitemia recorded was $1.51 \%( \pm 3.25)$. The birds species with a higher mean parasitemia were Caracara plancus Miller, $1777(3.49 \% \pm 3.46)$, followed by Saltator similis $(3.01 \%$ \pm 5.04 ) (Table 1).

Few developmental forms were found in the examined smears; most were trophozoites or young gametocytes of Haemoproteus spp. Thus, it was not possible to identify the species of infecting Plasmodium and Haemoproteus based on the morphological characteristics of schizonts or gametocytes (Fig.1).

Among the 80 birds analyzed by PCR, 66 were positive for Plasmodium spp. and Haemoproteus spp., with a preva-
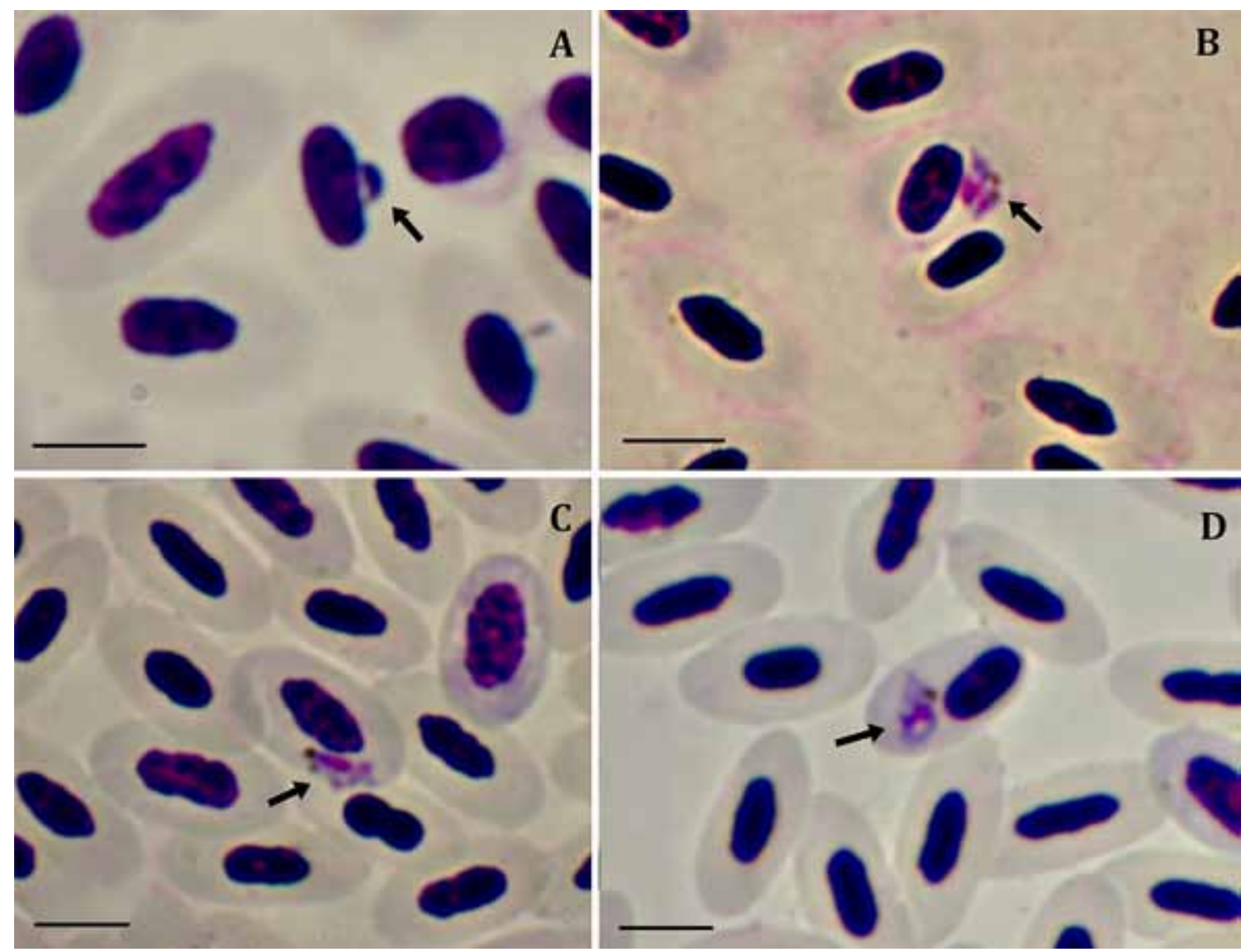

Fig.1. Evolutive forms of haemosporidian in Giemsa-stained blood smears from wild birds at IBAMA, Minas Gerais, Brazil. The arrows show in (A) trophozoite of Plasmodium sp., in (B) and in (C) schizonts of Plasmodium sp., and (D) young gametocyte of Haemoproteus sp. $1000 \mathrm{x}, \mathrm{bar}=5 \mu \mathrm{m}$. 
Table 1. Prevalence and parasite density of Plasmodium spp. and Haemoproteus spp. in species of wild birds in the Atlantic Forest of Minas Gerais, Brazil, as determined by blood smear and PCR analyzes

\begin{tabular}{|c|c|c|c|c|c|}
\hline $\begin{array}{l}\text { Birds family } \\
\text { and species }\end{array}$ & $\begin{array}{l}1^{\circ} \text { birds examined } \\
\text { in microscopy }\end{array}$ & $\begin{array}{l}\mathrm{n}^{\circ} \text { birds infected } \\
\text { in microscopy }\end{array}$ & $\begin{array}{l}\text { Mean parasitemia } \\
\text { in microscopy (\%) }\end{array}$ & $\begin{array}{c}\mathrm{n}^{\circ} \text { birds examined } \\
\text { in PCR }\end{array}$ & $\begin{array}{c}\mathrm{n}^{\circ} \text { birds infected } \\
\text { in PCR }\end{array}$ \\
\hline \multicolumn{6}{|l|}{ Accipitridae } \\
\hline Rupornis magnirostris (Gmelin, 1788) & 3 & 3 & 0.21 & 3 & 2 \\
\hline \multicolumn{6}{|l|}{ Falconidae } \\
\hline Caracara plancus (Miller, 1777) & 7 & 7 & 3.49 & 6 & 5 \\
\hline Falco sparverius Linnaeus, 1758 & 1 & 0 & 0 & 0 & 0 \\
\hline \multicolumn{6}{|l|}{ Columbidae } \\
\hline Columbina talpacoti (Temminck, 1811) & 1 & 1 & 0.58 & 1 & 0 \\
\hline \multicolumn{6}{|l|}{ Psittacidae } \\
\hline Ara ararauna (Linnaeus, 1758) & 1 & 0 & 0 & 1 & 1 \\
\hline Ara chloropterus Gray, 1859 & 1 & 1 & 0.49 & 1 & 1 \\
\hline Primolius maracana (Vieillot, 1816) & 4 & 2 & 0.35 & 1 & 0 \\
\hline $\begin{array}{l}\text { Psittacara leucophthalmus } \\
\text { (Statius Muller, 1776) }\end{array}$ & 20 & 18 & 1.34 & 18 & 16 \\
\hline Eupsittula aurea (Gmelin, 1788) & 3 & 3 & 0.56 & 3 & 2 \\
\hline Pionus maximiliani (Kuhl, 1820) & 2 & 1 & 0.33 & 2 & 1 \\
\hline Amazona vinacea (Kuhl, 1820) & 1 & 1 & 0.19 & 1 & 1 \\
\hline Amazona amazonica (Linnaeus, 1766) & 2 & 1 & 0.84 & 1 & 1 \\
\hline Amazona aestiva (Linnaeus, 1758) & 2 & 2 & 0.11 & 0 & 0 \\
\hline \multicolumn{6}{|l|}{ Strigidae } \\
\hline Strix virgata (Cassin, 1849) & 1 & 0 & 0 & 0 & 0 \\
\hline Athene cunicularia (Molina, 1782) & 1 & 1 & 0.09 & 1 & 1 \\
\hline Asio stygius (Wagler, 1832) & 2 & 0 & 0 & 2 & 2 \\
\hline \multicolumn{6}{|l|}{ Ramphastidae } \\
\hline Ramphastos toco Statius Muller, 1776 & 5 & 4 & 0.09 & 3 & 2 \\
\hline Pteroglossus aracari (Linnaeus, 1758 ) & 1 & 1 & 0.84 & 0 & 0 \\
\hline \multicolumn{6}{|l|}{ Picidae } \\
\hline Colaptes campestris (Vieillot, 1818) & 1 & 1 & 0.05 & 0 & 0 \\
\hline \multicolumn{6}{|l|}{ Tyrannidae } \\
\hline Pitangus sulphuratus (Linnaeus, 1766) & 2 & 1 & 0.66 & 1 & 0 \\
\hline \multicolumn{6}{|l|}{ Turdidae } \\
\hline Turdus rufiventris Vieillot, 1818 & 2 & 2 & 0.49 & 2 & 2 \\
\hline \multicolumn{6}{|l|}{ Mimidae } \\
\hline Mimus saturninus (Lichtenstein, 1823) & 1 & 1 & 0.09 & 0 & 0 \\
\hline \multicolumn{6}{|l|}{ Thraupidae } \\
\hline Saltator fuliginosus (Daudin, 1800) & 1 & 1 & 0.3 & 1 & 0 \\
\hline \multicolumn{5}{|l|}{ \& Lafresnaye, 1837} & 21 \\
\hline Ramphocelus bresilius (Linnaeus, 1766) & 1 & 1 & 0.07 & 0 & 0 \\
\hline Lanio pileatus (Wied, 1821) & 2 & 2 & 0.17 & 1 & 1 \\
\hline Paroaria dominicana (Linnaeus, 1758) & 1 & 1 & 0.8 & 0 & 0 \\
\hline Tangara sayaca (Linnaeus, 1766) & 1 & 1 & 0.02 & 0 & 0 \\
\hline Tangara palmarum (Wied, 1823) & 1 & 1 & 0.65 & 1 & 1 \\
\hline $\begin{array}{l}\text { Schistochlamys ruficapillus } \\
\text { (Vieillot, 1817) }\end{array}$ & 1 & 0 & 0 & 0 & 0 \\
\hline \multicolumn{6}{|l|}{ Emberizidae } \\
\hline $\begin{array}{l}\text { Zonotrichia capensis } \\
\text { (Statius Muller, 1776) }\end{array}$ & 2 & 1 & 0 & 2 & 2 \\
\hline Sicalis flaveola (Linnaeus, 1766) & 2 & 1 & 0 & 1 & 0 \\
\hline \multicolumn{6}{|l|}{ Cardinalidae } \\
\hline Cyanoloxia brissonii (Lichtenstein, 1823) & 2 & 2 & 2.02 & 2 & 2 \\
\hline \multicolumn{6}{|l|}{ Icteridae } \\
\hline Icterus jamacaii (Gmelin, 1788) & 1 & 1 & 0.1 & 0 & 0 \\
\hline Gnorimopsar chopi (Vieillot, 1819) & 2 & 1 & 0.04 & 0 & 0 \\
\hline Chrysomus ruficapillus (Vieillot, 1819) & 1 & 1 & 0.1 & 1 & 1 \\
\hline OVERALL & 119 & 99 (83.19\%) & $1.51( \pm 3.25)$ & 80 & 65 (81.3\%) \\
\hline
\end{tabular}

lence of $81.3 \%$. Although $12.5 \%(n=10)$ were positive by microscopy and negative by PCR, and $5 \%(n=4)$ were negative by both diagnostic techniques (Table 1 ).

The parasitized birds were distributed among 12 families and 24 species. Among the bird species analyzed, Columbina talpacoti Temminck 1811, Primolius maracana Vieillot, 1816, Pitangus sulphuratus Linnaeus, 1766, Saltator fuliginosus Daudin, 1800 and Sicalis flaveola Linnaeus,
1766 not were parasitized by Plasmodium spp. and Haemoproteus spp. (Table 1 ).

The reproducibility of the PCR method was confirmed by repeating the amplification of $20 \%$ of the samples.

\section{DISCUSSION}

The prevalence of haemosporidians observed in this study ( $83.19 \%$ by microscopy and $81.3 \%$ by PCR) can be consi- 
dered high when compared to other studies conducted in Brazil such as Ribeiro et al. (2005) with 39.6\%, Fecchio et al. $(2007,2011,2013)$ with $6.9 \%, 10.7 \%$ and $21 \%$ respectively, Belo et al. (2009) with $36 \%$ in psittacine birds kept in captivity, Lima et al. (2010) with 6.1\%, Sebaio et al. (2010) with 15.8\%, Belo et al. (2011) with 46\% studying birds of cerrado habitat of Brazil, Andery et al. (2013) with $13.5 \%$ studying birds of prey kept in captivity, Lacorte et al. (2013) with 35.3\% in birds of Southeast Brazil and Vanstreels et al. (2014) with 64\%. Among the studies conducted in Brazil, the present records the highest prevalence of Plasmodium spp. and Haemoproteus spp. in Brazilian wild birds in captivity.

The high prevalence of haemosporidian found in the present study may be related to the captive conditions, whereby the birds are kept in close proximity, which does not reflect the natural conditions of many species. Captivity may facilitate the exposure of birds to malaria vectors, including blood-sucking dipterous insects of the family Culicidae, which are common in tropical regions and disturbed areas (Valkiūnas 2005). These insects are also found near cage ponds, which can serve as breeding grounds for disease-transmitting insects.

White et al. (1978) suggested that the great diversity of neotropical birds, coupled with the large number of endemic species, could offer a great potential for high prevalence of bird hematozoa in relation to the Nearctic. Infection with Plasmodium spp. can have a strong negative impact on the host, especially when a bird species is exposed to the parasite for the first time (Van Riper III et al. 1986) or when birds are exposed to Plasmodium species that are not found in their natural environment. For example, the mortality of penguins, Spheniscus magellanicus Forster, 1781, with malarial infection caused by Plasmodium relictum Grassi et Feletti, 1891 at a zoo in Brazil was high (Bueno et al. 2010). Another example is the extinction of native birds in Hawaii due to the introduction of a new species of Plasmodium (Atkinson et al. 2000, Bensch et al. 2000). These findings confirm the risk that captive birds can represent to birds living free in nature because many are reintroduced into local preserve and can therefore expose different species to parasites acquired in captivity.

According to Ribeiro et al. (2005), the prevalence of infection should be related to the biological and behavioral characteristics of the host, such as the kind type of nest, as an open nest can expose the bird to more vectors than a closed nest. In addition, the participation of birds in flocks with other species, sex, age and feeding behavior can alter the possibility of contact with vectors and physiological changes that can make the bird more susceptible to hemoparasites. In captivity, the biological and behavioral characteristics of birds can be modified, and these conditions may be different from the natural, in which many birds do not assemble in flocks. Fecchio et al. (2011) showed the influence of the socialization of birds from the Brazilian Cerrado on the prevalence of hemoparasites, reporting a significant difference between birds living in groups and solitary birds, with a higher prevalence of haemosporidians in the social birds. These authors also observed a higher prevalence in birds living in captivity, which may explain the high prevalence found in this study, because the birds examined were from illegal captivity.

The mean total parasitemia found (1.51\%) can be considered low when compared with other studies. Ribeiro et al. (2005), for example, found an average of $2.3 \%$ parasitemia. This variable can be directly related to the pathogenicity of the infection, which in most cases is subclinical, and the appearance of clinical signs may be related to acute infections, with a significant increase in parasitemia (Atkinson et al. 1995). Parasitemia may be influenced by several factors such as the immunity of the bird, the stage of infection and the time in which it is established, the species of parasite and host, the sex and age of the host and intrinsic host characteristics such as the presence of sex hormones (Remple 2004, Valkiūnas 2005).

Although some studies such as those of Richard et al. (2002), Waldenström et al. (2004) and Garamszegi (2010) show the sensitivity of molecular analyses, PCR can mask the presence of more than one parasite in the blood, particularly in birds with low parasitemia, as in some cases of co-infections, reinforcing the need to also perform a microscopic examination (Jarvi et al. 2002, Valkiūnas et al. 2006, 2009b, Martínez et al. 2009, Zehtindjiev et al. 2011). In the study by Valkiūnas et al. (2009a), microscopic examination was more sensitive than PCR for the detection of co-infections. However, as in the present study, the overall mean prevalence was similar between the two methods ( $83.19 \%$ by microscopy and $81.3 \%$ by PCR). In Europe, Krone et al. (2008), studying Falconiformes in captivity, and Križanauskiené et al. (2006), studying wild passerines, assessed the prevalence of haemosporidian by microscopy and PCR for of cyt $b$ gene amplification and found that the results were similar when comparing the two methods of diagnosis. Other authors have also highlighted the prevalence of infection congruence between molecular and morphological analyses (Perkins and Schall 2002, Križanauskiené et al. 2006, 2010, Hellgren et al. 2007, Palinauskas et al. 2007, Valkiūnas et al. 2008, 2009a, 2014, Braga et al. 2011).

It is important to emphasize that, in most cases, the identification of haemosporidian species occurs through features observed by microscopy, such as the erythrocytic stages, including the length, width, area, size and number of hemozoin granules (Garnham 1966, Valkiūnas 2005, Martinsen et al. 2006). Therefore, this technique is still of great importance for the diagnosis of haemosporidian and should continue to be used together with molecular analyses.

Regarding the blood samples positive by microscopy but with no PCR amplification (12.5\%), it should be considered that the total amount of DNA extracted from blood is greater for birds than mammals due to erythrocyte nucleus, whereby the large amount of DNA can inhibit PCR, resulting in false negatives (Palinauskas et al., 2013b). Previous studies have reported similar false negatives using PCR-based methodology (Richard et al. 2002, Beadell et al. 2004, Valkiūnas et al. 2006, Cannell et al. 2013). This outcome may also be the result of degradation of the DNA sample over time or failure during DNA extraction (Ribeiro 
et al. 2005, Cannell et al. 2013). Additionally, the possibility of new species of Plasmodium tests with primers that amplify regions of different genes is necessary because a single gene can be insufficient for diagnosis. For example, Zehtindjiev et al. (2012) described the species Plasmodium polymorphum in blood smears and used the cytochrome $b$ gene but did not obtain PCR products, further emphasizing the importance of the use of microscopy with molecular biology.

\section{CONCLUSION}

The results may be of concern because different studies have revealed that hemoparasites can cause important changes in infected birds, even leading to death. Furthermore, these parasites may be related to the conservation of these animals (Derraik et al. 2008).

Haemosporidian infections can put captive birds at risk immediately or over the long term, which may justify the need for altering the management practices of birds targeted for reintroduction.

Infection with Plasmodium spp. and Haemoproteus spp. can be influenced by three factors: the presence of an appropriate vector, presence of a host bird and immune status of the host (Esparza et al. 2004).

It becomes important to pay attention to these conditions in the transfer of domestic and wild birds to other locations to prevent outbreaks of disease (Valkiūnas 2005).

It is necessary to recognize that hemoparasites are important etiologic agents and that more attention should be given to infections that can be transmitted in captivity and transferred to the natural habitat after reintroduction.

Acknowledgements.- We thank to Instituto Brasileiro do Meio Ambiente e dos Recursos Naturais Renováveis (IBAMA) for allowing the collection of birds in the study and Fundação de Amparo à Pesquisa do Estado de Minas Gerais (FAPEMIG) and Coordenação de Aperfeiçoamento de Pessoal de Nível Superior (CAPES)/Parasitologia Básica for financial support. To the Conselho Nacional de Desenvolvimento Científico e Tecnológico (CNPq) for Bolsa de Produtividade granted to Dra. Marta D’Agosto.

\section{REFERENCES}

Andery D.A., Ferreira Junior F.C., Araújo A.V., Vilela D.A.R., Marques M.V.R., Marin S.Y., Horta R.S., Ortiz M.C., Resende J.S. \& Martins N.R.S. 2013. Health assessment of raptors in triage in Belo Horizonte, MG, Brazil. Braz. J. Poult. Sci. 15:169-286.

Atkinson C.T., Woods K.L., Dusek R.J., Sileo L.S. \& Iko W.M. 1995. Wildlife disease and conservation in Hawaii: pathogenicity of avian malaria (Plasmodium relictum) in experimentally infected Iiwi (Vestiaria coccinea). Parasitology 111:59-69.

Atkinson C.T., Dusek R.J., Woods K.L. \& Iko W.M.J. 2000. Pathogenicity of avian malaria in experimentally-infected Hawaii Amakihi. J. Wildl. Dis. 36:197-204

Beadell J.S., Covas R., Gebhard C., Ishtiaq F., Melo M., Schmidt B.K., Perkins S.L., Graves G.R. \& Fleischer R.C. 2009. Host associations and evolutionary relationships of avian blood parasites from West Africa. Int. J. Parasitol. 39:257-266.

Belo N.O., Passos L.F., Júnior L.M.C., Goulart C.E., Sherlock T.M. \& Braga E.M. 2009. Avian malaria in captive psittacine birds: Detection by microscopy and 18S rRNA gene amplification. Prev. Vet. Med. 88:220-224.

Belo N.O., Pinheiro R.T., Reis S.E., Ricklefs R.O. \& Braga E.M. 2011. Host species and parasite lineage diversity of haemosporidians in three different environments with distinct levels of disturbance. Plos One 6:17654.
Bennett G. \& Lopes O.S. 1980. Blood parasites of some birds from São Paulo state, Brazil. Mem. Inst. Oswaldo Cruz 75:117-134.

Bensch S., Stjernman M., Hasselquist D., Ostman O., Hansson B., Westerdahl H. \& Pinheiro R.T. 2000. Host specificity in avian blood parasites: a study of Plasmodium and Haemoproteus mitochondrial DNA amplified from birds. Proc. R. Soc. Lond. B 267:1583-1589.

Bensch S., Hellgren 0. \& Pérez-Tris J. 2009. MalAvi: a public database of malaria parasites and related haemosporidians in avian hosts based on mitochondrial cytochrome b lineages. Mol. Ecol. Resour. 9:1353-1358.

Braga E.M., Silveira P., Belo N.O. \& Valkiūnas G. 2011. Recent advances in the study of avian malaria: an overview with an emphasis on the distribution of Plasmodium spp in Brazil. Mem. Inst. Oswaldo Cruz 106:3-11.

Bueno M.G., Lopez R.P.G., de Menezes R.M.T., Costa-Nascimento M.J., Lima G.F.M.C., Araújo R.A.S., Guida F.J.V. \& Kirchgatter K. 2010. Identification of Plasmodium relictum causing mortality in penguins (Spheniscus magellanicus) from São Paulo Zoo, Brazil. Vet. Parasitol. 173:123-127.

Bush A.O., Lafferty K.D., Lotz J.M. \& Shostak A.W. 1997. Parasitology meets ecology on its own terms: Margolis et al. revisited. J. Parasitol. 83:575-583.

Campbell T.W. 1995. Avian Hematology and Cytology. $2^{\text {nd }}$ ed. Iowa State, University Press, Ames, p.30-34.

Cannell B.L., Krasnec K.V., Campbell K., Jones H.I., Miller R.D. \& Stephens N. 2013. The pathology and pathogenicity of a novel Haemoproteus spp. infection in wild Little Penguins (Eudyptula minor). Vet. Parasitol. 197:74-84.

Chagas C.R.F., Valkiūnas G., Nery C.V.C., Henrique P.C., Gonzalez I.H.L., Monteiro E.F., Guimarães L.O., Romano C.M. \& Kirchgatter K. 2013. Plasmodium (Novyella) nucleophilum from an Egyptian Goose in São Paulo Zoo, Brazil: microscopic confirmation and molecular characterization. Int. J. Parasitol. Paras. Wildl. 2:286-291.

Clark N.J., Clegg S.M. \& Lima M.R. 2014. A review of global diversity in avian haemosporidians (Plasmodium and Haemoproteus: Haemosporida): new insights from molecular data. Int. J. Parasitol. 44:329-338.

Clark P., Boardman W.S.J. \& Raidal S.R. 2009. Atlas of Clinical Avian Hematology. Wiley-Blackwell, Oxford. 198p.

Derraik J.G.B., Tompkins D.M., Alley M.R., Holder P. \& Atkinson T. 2008. Epidemiology of an avian malaria outbreak in a native bird species (Mohoua ochrocephala) in New Zealand. J. R. Soc. N.Z. Zool. 38:237-242.

Donovan T.A., Schrenzel M., Tucker T.A., Pessier A.P. \& Stalis I.H. 2008. Hepatic hemorrhage, hemocoelom, and sudden death due to Haemoproteus infection in passerine birds: eleven cases. J. Vet. Diagn. Invest. 20:304-313.

Esparza B., Martínez-Abraín A., Merino S. \& Oro D. 2004. Brief report of Immunocompetence and the prevalence of haematozoan parasites in two long-lived seabirds. Ornis Fennica 81:40-46.

Fecchio A., Marini M.A. \& Braga E.M. 2007. Baixa prevalência de hemoparasitos em aves silvestres no cerrado brasileiro. Neotrop. Biol. Conserv. 2:127-135.

Fecchio A., Lima M.R., Silveira P., Braga E.M. \& Marini M.A. 2011. High prevalence of blood parasites in social birds from a neotropical savanna in Brazil. Emu - Aust. Ornithol. 111:132-138.

Fecchio A., Lima M.R., Svensson-Coelho M., Marini M.A. \& Ricklefs R.E. 2013. Structure and organization of an avian haemosporidian assemblage in a Neotropical savanna in Brazil. Parasitology 140:181-192.

Garamszegi L.Z. 2010. The sensitivity of microscopy and pcr-based detection methods affecting estimates of prevalence of blood parasites in birds. J. Parasitol. 96:1197-1203.

Garnham P.C. 1966. Malaria Parasites and other Haemosporidia. Blackwell Scientific Publications, Oxford. 1.114p.

Godfrey R.D., Fedynich A.M. \& Pence D.B. 1987. Quantification of hematozoa in blood smears. J. Wildl. Dis. 23:558-565.

Hellgren O., Waldenström J. \& Bensch S. 2004. A new PCR assay for simultaneous studies of Leucocytozoon, Plasmodium, and Haemoproteus from avian blood. J. Parasitol. 90:797-802.

Hellgren 0., Križanauskienė A., Valkiūnas G. \& Bensch S. 2007. Diversity and phylogeny of mitochondrial cytochrome $b$ lineages from six mor- 
phospecies of avian Haemoproteus (Haemosporida, Haemoproteidae). J. Parasitol. 93:889-896.

Jarvi S.I., Schultz J.J. \& Atkinson C.T. 2002. PCR diagnostics underestimate the prevalence of avian malaria (Plasmodium relictum) in experimentally-infected passerines. J. Parasitol. 88:153-158.

Khosravinia H. \& Ramesha K.P. 2007. Influence of EDTA and magnesium on DNA extraction from blood samples and specificity of polymerase chain reaction. Afr. J. Biotechnol. 6:184-187.

Križanauskiené A., Hellgren O., Kosarev V., Sokolov L., Bensch S. \& Valkiūnas G. 2006. Variation in host specificity between species of avian hemosporidian parasites: evidence from parasite morphology and cytochrome b gene sequences. Parasitology 92:1319-1324.

Križanauskiené A., Pérez-Tris J., Palinauskas V., Hellgren 0., Bensch S. \& Valkiūnas G. 2010. Molecular phylogenetic and morphological analysis of haemosporidian parasites (Haemosporida) in a naturally infected European songbird, the blackcap Sylvia atricapilla, with description of Haemoproteus pallidulus sp. nov. Parasitology 137:217-227.

Krone O., Waldenström J., Valkiūnas G., Lessow O., Müller K., iezhova T.A., Fickel J. \& Bensch S. 2008. Haemosporidian blood parasites in European birds of prey and owls. J. Parasitol. 94:709-715.

Lacorte G.A., Félix G.M.F., Pinheiro R.R.B., Chaves A.V., Almeida-Neto G., Neves F.S., Leite L.O., Santos F.R. \& Braga E.M. 2013. Exploring the Diversity and Distribution of Neotropical Avian Malaria Parasites - A Molecular Survey from Southeast Brazil. PLoS One 8:57770.

Lefèvre T., Roche B., Poulin R., Hurd H., Renaud F. \& Thomas F. 2008. Exploiting host compensatory responses: the 'must' of manipulation? Trends Parasitol. 24:435-439.

Lima M.R., Simpson L., Fecchio A. \& Kyaw C.M. 2010. Low prevalence of haemosporidian parasites in the introduced house sparrow (Passer domesticus) in Brazil. Acta Parasitol. 55:297-303.

Martínez J., La Puente J.M., Herrero J., Del Cerro S., Lobato E., Aguilar J.R., Vásquez R.A. \& Merino S. 2009. A restriction site to differentiate Plasmodium and Haemoproteus infections in birds: on the inefficiency of general primers for detection of mixed infections. Parasitology 136:713722.

Martinsen E.S., Paperna I. \& Schall J.J. 2006. Morphological versus molecular identification of avian Haemosporidia: an exploration of three species concepts. Parasitol. 133:279-288.

Martinsen E.S., Perkins S. \& Schall J.J. 2008. A three-genome phylogeny of malaria parasites (Plasmodium and closely related genera): evolution of life-history traits and host switches. Mol. Phylogenet. Evol. 47:261273.

Massey J.G., Graczyk T.K. \& Cranfield M.R. 1996. Characteristics of naturally acquired Plasmodium relictum capistranoae infections in native Hawaiians crows in Hawaii. J. Parasitol. 82:182-185.

Macchi B.M., Miranda F.J.B., Souza F.S., Carvalho E.C.Q., Albernaz A.P., Nascimento J.L.M. \& DaMatta R.A. 2013. Chickens treated with a nitric oxide inhibitor became more resistant to Plasmodium gallinaceum infection due to reduced anemia, thrombocytopenia and inflammation. Vet. Res. 44:8.

Merino S., Moreno J., Vásquez R.A., Martínez J., Sánchez-Monsálvez I., Estades C.F., Ippi S., Sabat P., Rozzi R. \& Mcgehee S. 2008. Haematozoa in forest birds from southern Chile: Latitudinal gradients in prevalence and parasite lineage richness. Aust. Ecol. 33:329-340.

Palinauskas V., Kosarev V., Shapoval A., Bensch S. \& Valkiūnas G. 2007. Comparison of mitochondrial cytochrome b lineages and morphospecies of two avian malaria parasites of the subgenera Haemamoeba and Giovannolaia (Haemosporida: Plasmodiidae). Zootaxa 1626:39-50.

Palinauskas V., Valkiūnas G., Križanauskiené A., Bensch S. \& Bolshakov C.V. 2009. Plasmodium relictum (lineage P- SGS1): further observation of effects on experimentally infected passeriform birds, with remarks on treatment with Malarone ${ }^{\mathrm{T} M}$. Exp. Parasitol. 123:134-139.

Palinauskas V., Valkiūnas G., Bolshakov C.V. \& Bensch S. 2011. Plasmodium relictum (lineage SGS1) and Plasmodium ashfordi (lineage GRW2): The effects of the co-infection on experimentally infected passerine birds. Exp. Parasitol. 127:527-533.
Palinauskas V., Iezhova T.A., Križanauskiené A., Markovets M.Y., Bensch S. \& Valkiūnas G. 2013a. Molecular characterization and distribution of Haemoproteus minutus (Haemosporida, Haemoproteidae): a pathogenic avian parasite. Parasitol. Int. 62:358-363.

Palinauskas V., Križanauskienė A., Iezhova T.A., Bolshakov C.V., Jönsson J., Bensch S. \& Valkiūnas G. 2013b. A new method for isolation of purified genomic DNA from haemosporidian parasites inhabiting nucleated red blood cells. Exp. Parasitol. 133:275-280.

Perkins S.L. \& Schall J.J. 2002. A molecular phylogeny of malaria parasites recovered from cytochrome b gene sequences. J. Parasitol. 88: 972-978.

Remple J.D. 2004. Intracellular Hematozoa of Raptors: A Review and Update. J Avian Med. Surg. 18(2):75-88.

Ribeiro S.F., Sebaio F., Branquinho F.C., Marini M.A., Vago A.R. \& Braga E.M. 2005. Avian malaria in Brazilian passerine birds: parasitism detected by nested PCR using DNA from stained blood smears. Parasitol. 130:261267.

Richard F.A., Sehgal R.N.M., Jones H.I. \& Smith T.B. 2002. A comparative analysis of PCR-based detection methods for avian malaria. J. Parasitol. 88:819-822.

Ricklefs R.E. \& Fallon S.M. 2002. Diversification and host switching in avian malaria parasites. Proc. R. Soc. B 269:885-892.

Sebaio F., Braga E.M., Branquinho F., Manica L.T. \& Marini M.A. 2010. Blood parasites in Brazilian Atlantic Forest birds: effects of fragment size and habitat dependency. Bird Conserv. Int. 20:432-439.

Silveira P., Belo N.O., Lacorte G.A., Kolesnikovas C.K.M., Vanstreels R.E.T., Steindel M., Catão-Dias J.L., Valkiūnas G. \& Braga E.M. 2013. Parasitological and new molecular-phylogenetic characterization of the malaria parasite Plasmodium tejerai in South American penguins. Parasitol. Int. 62:165-171

Valkiūnas G. 2005. Avian Malaria Parasites and Other Haemosporidia. CRC Press, Boca Raton, FL. 946p.

Valkiūnas G., Bensch S., Iezhova T.A., Križanauskiené A., Hellgren O. \& Bolshakov C.V. 2006. Nested cytochrome b polymerase chain reaction diagnostics underestimate mixed infections of avian blood haemosporidian parasites: microscopy is still essential. J. Parasitol. 92:418-422.

Valkiūnas G., Iezhova T.A., Križanauskiené A., Palinauskas V., Sehgal R.N.M. $\&$ Bensch S. 2008. A comparative analysis of microscopy and pcr-based detection methods for blood parasites. J. Parasitol. 94:1395-1401.

Valkiūnas G., Iezhova T.A., Loiseau C., Smith T.B \& Sehgal R.N.M. 2009a. New malaria parasites of the subgenus Novyella in African rainforest birds, with remarks on their high prevalence, classification and diagnostics. Parasitol. Res. 104:1061-1077.

Valkiūnas G., Iezhova T.A., Loiseau C. \& Sehgal R.N.M. 2009b. Nested cytochrome b polymerase chain reaction diagnostics detect sporozoites of hemosporidian parasites in peripheral blood of naturally infected birds. J. Parasitol. 95:1512-1515.

Valkiūnas G., Santiago-Alarcon D., Levin I.I., Iezhova T.A. \& Parker P.G. 2010. A new Haemoproteus species (Haemosporida: Haemoproteidae) from the endemic Galapagos dove Zenaida galapagoensis, with remarks on the parasite distribution, vectors, and molecular diagnostics. J. Parasitol. 96:783-792.

Valkiūnas G., Iezhova T.A., Evans E., Carlson J.S., Martínez-Gómez J.E. \& Sehgal R.N.M. 2013. Two new Haemoproteus species (Haemosporida: Haemoproteidae) from columbiform birds. J. Parasitol. 99(3):513-521.

Valkiūnas G., Palinauskas V., Ilgūnas M., Bukauskaitė D., Dimitrov D., Bernotienè R., Zehtindjiev P., Ilieva M. \& Iezhova T.A. 2014. Molecular characterization of five widespread avian haemosporidian parasites (Haemosporida), with perspectives on the PCR-based detection of haemosporidians in wildlife. Parasitol. Res. 113:2251-2263.

Van Riper III C., Van Riper S.G., Gaff M.L. \& Laird M. 1986. The epizootiology and ecological significance of malaria in Hawaii land birds. Ecol. Monogr. 56:327-344.

Vanstreels R.E.T., Kolesnikovas C.K.M., Sandri S., Silveira P., Belo N.O., Junior F.C.F., Epiphanio S., Steindel M., Braga E.M., Catão-Dias J.L. 2014. Outbreak of Avian Malaria Associated to Multiple Species of Plasmodium 
in Magellanic Penguins Undergoing Rehabilitation in Southern Brazil. PLoS One 9:e94994.

Waldenström J., Bensch S., Hasselquist D. \& Ostman 0. 2004. A new nested polymerase chain reaction method very efficient in detecting Plasmodium and Haemoproteus infections from avian blood. J. Parasitol. 90:191-194.

White E.M., Greiner E.C., Bennett G.F. \& Herman C.M. 1978. Distribution of the hematozoa of Neotropical birds. Rev. Biol. Trop. 26:43-102.

Woodworth-Lynas C.B., Caines J.R. \& Bennett G.F. 1989. Prevalence of avian Haematozoa in São Paulo state, Brazil. Mem. Inst. Oswaldo Cruz 84:515-526
Zehtindjiev P., Križanauskiené A., Scebba S., Dimitrov D., Valkiūnas G., Hegemann A., Tieleman B.I. \& Bensch S. 2011. Haemosporidian infections in skylarks (Alauda arvensis): a comparative PCR-based and microscopy study on the parasite diversity and prevalence in southern Italy and the Netherlands. Eur. J. Wildl. Res. 58:335-344.

Zehtindjiev P., Križanauskiené A., Bensch S., Palinauskas V., Asghar M., Dimitrov D., Scebba S. \& Valkiūnas G. 2012. A new morphologically distinct avian malaria parasite that fails detection by established polymerase chain reaction-based protocols for amplification of the cytochrome b gene. J. Parasitol. 98:657-665. 